\title{
PENILAIAN RANAH PSIKOMOTORIK SISWA DALAM PELAJARAN BAHASA
}

\author{
Andi Nurwati \\ IAIN Sultan Amai Gorontalo, Indonesia \\ nurwati.andin@gmail.com
}

\begin{abstract}
Abstrak
Penilaian tidak dapat dipisahkan dari kegiatan belajar mengajar. Untuk memperoleh keterampilan berbahasa yang baik, maka penilaian psikomotorik siswa dalam proses belajar mengajar perlu dilakukan. Penelitian ini bertujuan untuk mengetahui penilaian psikomotorik siswa dengan menggunakan metode library research. Hasilnya menunjukkan bahwa penilaian hasil belajar psikomotor atau keterampilan harus mencakup persiapan, proses, dan produk. Ketiganya harus seimbang. Penilaian dapat dilakukan pada saat proses berlangsung yaitu pada waktu peserta didik melakukan praktik, atau sesudah proses berlangsung dengan cara mengetes peserta didik. Sebagai alternatif, tes pragmatik adalah tes untuk kompetensi psikomotorik yang ditawarkan. Tes tersebut adalah dikte, berbicara, pemahaman parafrase, jawaban pertanyaan dan teknik cloze.

Kata kunci: keterampilan berbahasa, penilaian psikomotorik, proses belajar mengajar
\end{abstract}

\begin{abstract}
Assessment cannot be separated from teaching and learning process. For having good language skills, psychomotoric assessment should be used. The purpose of this study was knowing the psychomotoric assessment in language teaching. This study used library research method. The result showed that assessment of psychomotoric learning
\end{abstract}


Andi Nurwati

result or the skills should cover preparation, process, and product. These three points dhould be balanced. The assessment can be done when they have teaching and learning process. The appropriate time is when students practice or after the students having learning process by testing them. As the alternatives, pragmatic test is offered. It is for measuring the students' psychomotoric competence. Those tests are dictation, understanding parafrase, answering question and cloze technique.

Keywords: language skill, psychomotoric assessment, teaching and learning process

\section{A. Pendahuluan}

Penilaian merupakan suatu kegiatan yang tidak mungkin dipisahkan dari kegiatan pendidikan dan pengajaran secara umum. Semua kegiatan pendidikan yang dilakukan harus selalu diikuti atau disertai dengan kegiatan penilaian. Mengingat kegiatan pendidikan dan pengajaran merupakan suatu proses, yaitu proses mencapai sejumlah tujuan yang telah ditetapkan, maka penilaian yang dilakukan harus juga merupakan proses. Penilaian dapat diartikan sebagai suatu proses untuk mengukur kadar pencapaian tujuan. Pengertian ini sesuai dengan pendapat Tuckman dalam Nurgiyantoro (2001: 5) yang mengartikan penilaian sebagai suatu proses untuk mengetahui (menguji) apakah suatu kegiatan, proses kegiatan, keluaran suatu program telah sesuai dengan tujuan atau kriteria yang telah ditentukan.

Pasal 25 (4) Peraturan Pemerintah Nomor 19 tahun 2005 tentang Standar Nasional Pendidikan menjelaskan bahwa kompetensi lulusan mencakup sikap, pengetahuan, dan keterampilan. Ini berarti bahwa pembelajaran dan penilaian harus mengembangkan kompetensi peserta didik yang berhubungan dengan ranah afektif (sikap), kognitif (pengetahuan), dan psikomotor (keterampilan). Dalam pelajaran bahasa baik Bahasa Indonesia maupun Bahasa Inggris dan Arab, komponen atau unsur kebahasaan yang dinilai adalah meliputi hal-hal yang menjadi cakupan pengajaran bahasa. Cakupan pengajaran bahasa meliputi kompetensi kebahasaan, keterampilan berbahasa, dan kesusasteraan.

Kompetensi kebahasaan berkaitan dengan pengetahuan 
tentang sistem bahasa, tentang stuktur, dan kosa kata. Keterampilan berbahasa dibedakan menjadi dua kelompok, yakni kemampuan memahami (comprehension) dan mempergunakan (production), masing-masing bersifat reseptif dan produktif. Menurut Harris dalam Nurgiyantoro (2001: 167) kemampuan reseptif merupakan proses decoding, proses usaha memahami apa yang dituturkan orang lain. Sebaliknya, kemampuan produktif merupakan proses encoding, proses usaha mengkomunikasikan ide, pikiran, atau perasaan melalui bentuk-bentuk kebahasaan. Untuk menilai kemampuan atau pencapai tujuan pembelajaran bahasa dikenal berbagai jenis tes kebahasaan. Yang pertama yaitu bersifat diskrit yaitu tes yang hanya menekankan atau menyangkut satu aspek kebahasaan pada satu waktu (Nurgiyantoro, 2001: 169). Kedua bersifat integratif, yaitu mengukur kemampuan siswa mempergunakan berbagai aspek kebahasaan atau beberapa keterampilan berbahasa. Ketiga, pragmatik merupakan suatu pendekatan dalam tes keterampilan (skills) berbahasa untuk mengukur seberapa baik siswa mempergunakan elemen-elemen bahasa sesuai dengan konteks komunikasi yang nyata. Dan keempat, tes komunikatif merupakan tes pragmatik yang lebih menekankan pada ketegasan dan kejelasan konteks, kejelasan yang tegas antara tes bahasa dengan aspek dan situasi-kondisi faktual dalam berkomunikasi.

Keterampilan berbahasa adalah hal penting dari proses pembelajaran bahasa, untuk mendapatkan hasil capaiannya maka penilaian psikomotorik adalah solusinya. Dalam penelitian ini, penilaian psikomotorik siswa inilah yang akan dibahas. Melalui metode library research, diharapkan hasil terbaik dapat diperoleh.

\section{B. Pembahasan}

\section{Pembelajaran Bahasa}

Pembelajaran mengandung makna kegiatan belajar. Oleh karena itu sebelum diuraikan tentang pembelajaran, perlu kiranya ditinjau tentang arti belajar itu. Belajar adalah suatu proses aktif yang dilakukan seseorang untuk mencapai suatu tujuan. Lebih lanjut, belajar adalah kegiatan yang dilakukan seseorang untuk memperoleh kemampuan baru dan suatu perubahan dalam kepribadian yang dimanifestasikan dalam perubahan penguasaan pola-pola respon 
atau tingkah laku yang baru. Di dalamnya mencakup perubahan keterampilan, kebiasaan, kesanggupan atau pemahaman. Menurut Muijs, Daniel dan David Reynolds (2008: 14), konsep belajar menurut pakar behavorisme yakni "something people do in response to external stimuli". Maksudnya, belajar adalah sesuatu yang orang lakukan dalam merespon rangsangan dari luar lebih lanjut. Klein, Stephen (2002:2) mendefinisikan "Learning as an experiential process resulting in a relatively permanent change in behavior that cannot be explained by temporary states, maturation, or innate response tendencies". Artinya adalah belajar sebagai "sebuah hasil proses pengalaman dalam sebuah perubahan yang relatif tetap dalam tingkah laku yang tidak dapat dijelaskan oleh pernyataan sementara, prematur, dengan alasan yang tendesius.

Berdasarkan definisi ini, belajar memiliki tiga komponen penting, yaitu: 1) Belajar mencerminkan perubahan tingkah laku; 2) Perubahan tingkah laku karena belajar bersifat permanen; 3) Perubahan tingkah laku dapat terjadi karena proses. Sementara Domjan (2005: 5) mengemukan bahwa belajar adalah perubahan yang kemungkinan dapat dilakukan.

Lebih lanjut dikemukan bahwa perilaku menyangkut aksi atau tindakan, aksi-aksi otot atau aksi-aksi kelenjar dan gabungan dari kedua macam aksi itu. Perhatian utama ialah perilaku verbal dari manusia, sebab dari tindakan-tindakan menulis, berbicara dan menyimak manusia dapat kita tentukan apakah perubahan-perubahan dalam perilaku telah terjadi. Perubahan dari "ba-ba" menjadi "bapak", dari menulis "se ko la" menjadi menulis "sekolah", memungkinkan kita untuk menyimpulkan bahwa belajar telah terjadi.

Pakar lain Winkel (2004: 590) menyatakan belajar sebagai suatu aktifitas mental/psikis, yang berlangsung dalam interaksi aktif dengan lingkungan, yang menghasilkan sejumlah perubahan dalam pengetahuan-pemahaman, keterampilan dan nilai sikap. Perubahan itu bersifat secara relatif konstan dan berbekas. Lebih lanjut Sudjana (1991: 5) menyatakan belajar adalah proses yang aktif, suatu fungsi dari keseluruhan lingkungan di sekitarnya. Sesuai dengan batasan tersebut, maka belajar dalam konteks pendidikan bahasa Indonesia terletak pada masalah-masalah perubahan pengetahuan kebahasaan, 
sikap berbahasa dan keterampilan berbahasa. Perubahan tersebut dapat berupa peningkatan pengetahuan tentang bahasa, peningkatan sikap berbahasa, dan peningkatan keterampilan berbahasa.

Bahasa menurut Pinker dalam buku Brown (2007: 6) adalah keterampilan khusus yang kompleks, berkembang dalam diri anakanak secara spontan, tanpa usaha sadar atau instruksi formal, dipakai tanpa memahami logika yang mendasarinya, secara kualitatif sama dalam diri setiap orang, dan berbeda dari kecakapan-kecakapan lain yang sifatnya lebih umum dalam hal memproses informasi atau berprilaku secara cerdas.

Lebih lanjut, bahasa menurut Brown (2007: 4) adalah alat sistematis untuk menyampaikan ide atau perasaan dengan menggunakan tanda, suara, gerakan yang telah disepakati atau tanda yang mempunyai makna. Ada tiga pandangan teoretis yang berbeda mengenai bahasa dan hakekat kecakapan berbahasa secara eksplisit atau secara implisit yaitu: 1) pandangan struktural, yang paling tradisional, yaitu pandangan bahwa 'bahasa adalah suatu sistem unsur-unsur yang berhubungan secara struktural bagi penyandian makna'. 2) Pandangan fungsional, pandangan bahwa bahasa merupakan wahana bagi ekspresi makna fungsional. Gerakan komunikatif dalam pengajaran bahasa menurut pandangan ini. Teori ini lebih menekankan dimensi semantik dan komunikatif daripada sekedar ciri-ciri gramatikal bahasa. 3) Pandangan interaksional, bahasa merupakan wahana bagi realisasi hubungan-hubungan antarpribadi dan bagi performansi transaksi-transaksi sosial di antara para individu.

Selanjutnya pembelajaran adalah kegiatan belajar yang dialami siswa dalam proses menguasai tujuan pembelajaran. Pembelajaran bersinonim dengan pengalaman belajar aktivitas belajar, proses belajar, dan kegiatan belajar. Ini sejalan dengan pendapat Piaget bahwa pembelajaran adalah proses perkembangan yang melibatkan perubahan, pemunculan diri, dan konstruksi, yang masing-masing dibangun di atas pengalaman-pengalaman pembelajaran sebelumnya (Brown, 2007: 13). Ciri-ciri pembelajaran adalah berupa kegiatan siswa, kegiatan berbahasa, yang dapat dikembangkan secara kreatif, relevan dengan komponen PBM dan pendekatan pengajaran bahasa. 
Pendekatan atau metode pengajaran bahasa mulai dari metode klasik yakni penerjemahan tata bahasa (grammar translation method), lalu metode langusng (direct method), metode audiolingual (audiolingual method) sampai pengajaran bahasa komunikatif (communicative language teaching). Pengajaran bahasa komunikatif inilah yang berkembang hingga dewasa ini. Hal ini dikarenakan relevansi dari fungsi bahasa sebagai sarana interaksi dalam kehidupan sosial masyarakat, terlebih dalam dunia pendidikan yakni dalam proses pembelajaran.

Sebelum melaksanakan proses belajar mengajar, secara aktual di dalam kelas, guru perlu menyiapkan rancangan pembelajaran dalam bentuk persiapan tertulis. Hal-hal yang perlu dikaji sebagai bahan pertimbangan untuk merancang proses belajar mengajar di dalam kelas, sekurang-kurangnya guru harus mengkaji dan menetapkan tujuan pembelajaran yang ingin dicapai, memilih dan menetapkan materi pembelajaran, menetapkan metode pengajaran yang cocok dan tepat, serta merancang penilaian untuk mengukur tingkat pencapaian tujuan yang telah ditetapkan.

Pengembangan pembelajaran menghasilkan seperangkat kegiatan belajar atau langkah-langkah pembelajaran. Langkahlangkah pembelajaran itu haruslah terperinci, sistematis, menunjang pencapaian tujuan khusus pembelajaran, beraneka dalam kegiatan berbahasa, serta efisiensi dan efektif. Pembelajaran beserta hasil pengembangannya berfungsi sebagai titik tolok penentuan komponen proses belajar mengajar, alokasi waktu, dan sebagai sarana untuk menyusun rancangan pembelajaran bahasa. Gagne menetapkan delapan jenis pembelajaran bahasa yakni; pembelajaran isyarat, pembelajaran stimulus-respon, perangkaian, asosiasi verbal, diskriminasi ganda, pembelajaran konsep, pembelajaran prinsip, dan pemecahan masalah (Brown, 2007: 107).

Pembelajaran dalam proses belajar mengajar mempunyai tujuan yang hendak dicapai, berhubungan dengan bahan apa yang harus dipelajari, metode apa yang akan digunakan dan evaluasi seperti apa yang hendak dilakukan seharusnya sudah dibuat pengajar sebelum mengajar. Keseluruhan proses ini tertuang dalam rancangan pembelajaran. Rancangan pembelajaran merupakan perencanaan 
proses dan kegiatan pembelajaran. Rancangan yang baik diharapkan dapat dicapai pembelajaran yang efektif. Materi pelajaran yang tertuang dalam rancangan pembelajaran merupakan hal inti dalam proses belajar mengajar. (Iskandarwassid dan Dadang Sunendar, 2008: 201).

\section{Penilaian Psikomotorik}

Ranah psikomotor berhubungan dengan hasil belajar yang pencapaiannya melalui keterampilan manipulasi yang melibatkan otot dan kekuatan fisik. Mata pelajaran yang berkaitan dengan psikomotor adalah mata pelajaran yang lebih beorientasi pada gerakan dan menekankan pada reaksi-reaksi fisik dan keterampilan tangan. Keterampilan itu sendiri menunjukkan tingkat keahlian seseorang dalam suatu tugas atau sekumpulan tugas tertentu.

Menurut Mardapi (2003: 143), keterampilan psikomotor ada enam tahap, yaitu gerakan refleks, gerakan dasar, kemampuan perseptual, gerakan fisik, gerakan terampil, dan komunikasi nondiskursif. Gerakan refleks adalah respons motorik atau gerak tanpa sadar yang muncul ketika bayi lahir. Gerakan dasar adalah gerakan yang mengarah pada keterampilan komplek yang khusus. Kemampuan perseptual adalah kombinasi kemampuan kognitif dan motorik atau gerak. Kemampuan fisik adalah kemampuan untuk mengembangkan gerakan terampil. Gerakan terampil adalah gerakan yang memerlukan belajar, seperti keterampilan dalam olah raga. Komunikasi nondiskursif adalah kemampuan berkomunikasi dengan menggunakan gerakan.

Buttler (1972: 13) membagi hasil belajar psikomotor menjadi tiga, yaitu: specific responding, motor chaining, rule using. Pada tingkat specific responding, peserta didik mampu merespons hal-hal yang sifatnya fisik, (yang dapat didengar, dilihat, atau diraba), atau melakukan keterampilan yang sifatnya tunggal, misalnya memegang raket, memegang bed untuk tenis meja. Pada motor chaining peserta didik sudah mampu menggabungkan lebih dari dua keterampilan dasar menjadi satu keterampilan gabungan, misalnya memukul bola, menggergaji, menggunakan jangka sorong, dan lain-lain. Pada tingkat rule using peserta didik sudah dapat menggunakan pengalamannya untuk melakukan keterampilan yang komplek, misalnya bagaimana 
memukul bola secara tepat agar dengan tenaga yang sama hasilnya lebih baik.

Dalam tahapannya, hasil belajar psikomotor dapat dibedakan menjadi lima tahap, yaitu: imitasi, manipulasi, presisi, artikulasi, dan naturalisasi. Imitasi adalah kemampuan melakukan kegiatan-kegiatan sederhana dan sama persis dengan yang dilihat atau diperhatikan sebelumnya. Contohnya, seorang peserta didik dapat mengulang pengucapan sebuah kata setelah gurunya mengucapkan sebelumnya. Manipulasi adalah kemampuan melakukan kegiatan sederhana yang belum pernah dilihat tetapi berdasarkan pada pedoman atau petunjuk saja. Sebagai contoh, seorang peserta didik dapat menulis menginterpretasi gambar dalam sebuah karangan hanya berdasarkan pada petunjuk guru atau teori yang dibacanya.

Sebagaimana dijelaskan beberapa pakar di atas, ranah psikomotorik adalah segala sesuatu yang berhubungan dengan aktifitas otot, fisik, atau gerakan-gerakan anggota badan. Keluaran hasil belajar yang bersifat psikomotoris adalah keterampilan-keterampilan gerak tertentu yang diperoleh setelah mengalami peristiwa belajar. Pengertian "keterampilan gerak" tersebut hendaknya senantiasa dikaitkan dengan "gerak" keterampilan atau penampilan yang sesuai dengan bidang study yang diajarkan. Oleh karena itu, "gerak" -an otot sebagai hasil belajar sastra tentu saja akan berbeda gerakan otot sebagai hasil belajar bidang keolahragaan misalnya.

Penilaian hasil tes belajar psikomotoris harus juga dilakukan dengan alat tes yang berupa tes perbuatan. Penilaian dilakukan dengan jalan pengamatan. Misalnya tes psikomotorik kesastraan -walau tetap ada unsur kognitif dan sikap karena yang utama adalah kadarnya-tugas berdeklamasi, membaca puisi, cerpen, drama (kesemuanya dengan gerak mimic dan pantomimic), dramatisasi (bentuk yang lebih sungguhan: pentas drama), dan lain-lain. Untuk melakukan pengamatan, terlebih dahulu kita perlu menentukan aspek-aspek yang dinilai sekaligus criteria penilaiannya. Aspek-aspek yang dinilai untuk beberapa contoh di atas misalnya pemahaman, penghayatan, intonasi, ekspresi, kewajaran, dan sebagainya. Sedang kriteria penilaiannya misalnya mempergunakan angka terendah 40 dan tertinggi 100 . 
Penilaian terhadap aspek perbuatan tersebut menuntut tindakan dan sikap teliti terhadap tiap jenis penampilan siswa. Karena sifatnya yang kompleks, seperti halnya ranah afektif di atas, penilaian ranah psikomotor sebaiknya dilakukan dalam proses, yaitu sewaktu pengajaran masih berlangsung. Penilaian tidak harus dilakukan secara khusus, dalam arti menyelenggarakan tes itu, melainkan dapat bersifat kesewaktuan dan kapan saja. Penilaian ini akan lebih mencerminkan penampilan dan sikap siswa sesungguhnya.

\section{Pembelajaran Psikomotor}

Menurut Kamus Besar Bahasa Indonesia oleh Hasan dkk (2005: 553), kemampuan adalah kesanggupan, kecakapan, kekuatan : kita berusaha dengan diri sendiri. Sedangkan menurut Arikunto (2001:122), "ranah psikomotorik berhubungan erat dengan kerja otot sehingga menyebabkan geraknya tubuh atau bagian-bagiannya”. Selain itu, Hamalik dalam Laksono (2011:28) juga menambahkan bahwa siswa adalah komponen masukan dalam sistem pendidikan yang selanjutnya akan diproses dalam pendidikan sehingga menjadi manusia yang berkualitas sesuai dengan tujuan pendidikan nasional.

Dari ketiga defini tersebut dapat diketahui bahwa pembelajar psikomotor adalah pembelajar yang senantiasa berusaha atau bekerja untuk memperoleh kecakapan sehingga dia dapat mencapai tujuan pendidikan nasional.

\section{Penilaian Hasil Belajar Psikomotor}

Agar memperoleh hasil maksimal, penilaian harus berdasarkan pada tujuan yang ingin dicapai. Adapun untuk menilai hasil belajar psikomotor siswa, Arifin (1991:11) menjelaskan bahwa ada beberapa prinsip yang harus diaplikasikan. Prinsip-prinsip tersebut adalah sebagai berikut.

a. Kontinuitas

Penilaian tidak boleh dilakukan secara insidental. Karena pendidkan itu sendiri adalah proses yang kontinu, maka penilaian harus dilakukan terus-menerus. Hasil penilaian yang diperoleh pada suatu waktu harus senantiasa dihubungkan dengan hasil-hasil dalam waktu sebelumnya, sehingga dapat diperoleh gambaran yang jelas dan berarti tentang perkembangan peserta didik. 
Andi Nurwati

b. Keseluruhan

Penilaian harus dilakukan secara menyeluruh terhadap seluruh objek yang mencakup semua dimensi yag ada dalam aspek psikomotorik. Seluruh komponen harus mendapatkan perhatian dan pertimbanagan yang sama dalam mengambil keputusan.

c. Objektifitas

Penilaian hendaknya dilaksanakan seobjektif mungkin. Oleh sebab itu perasaan-perasaan, keinginan-keinginan, prasangka-prasangka yang bersifat negatif harus dijauhkan. Penilaian harus didasarkan pada kenyataan yang sebenarnya.

d. Kooperatif

Prinsip ini sangat erat kaitanya dengan prinsip-prinsip di atas. Dalam prinsip ini terkandung maksud bahwa setiap kegiatan penilaian hendaknya dilakukan bersama-sama oleh pihak yang bersangkutan sperti guru, kepala sekolah, orang tua bahkan siswa.

\section{Tes Pragmatik}

Tes pragmatik merupakan suatu pendekatan dalam tes keterampilan (skills) berbahasa untuk mengukur seberapa baik siswa mempergunakan elemen-elemen bahasa sesuai dengan konteks komunikasi yang nyata (Oller, dalam Nurgiyantoro, 2001: 177). Tes pragmatik sebagai tes bahasa untuk kemampuan produktif yakni kemampuan berbicara dan menulis. Kegiatan berbicara merupakan kegiatan menghasilkan bahasa dan mengkomunikasikan ide dan pikiran secara lisan. Unsur bahasa dan pikiran merupakan dua unsur yang tak dapat dipisahkan dalam kegiatan berbicara. Untuk berbicara dengan baik, harus dikuasai secara aktif struktur dan kosa kata bahasa yang bersangkutan yang akan dipergunakan sebagai wadah untuk menampung pikiran yang akan dikemukakan, disamping sistem bunyi bahasa itu. Masalah kelancaran dan ketetapan bahasa serta kejelasan pikiran merupakan hal yang sering diteskan (dinilai) dalam kegiatan berbicara.

Secara prinsipial kegiatan menulis tidak berbeda dengan kegiatan berbicara, kegiatan menghasilkan bahasa dan mengkomunikasikan pikiran secara tertulis. Tes keterampilan 
menulispun akan berkisar pada ketepatan bahasa yang dipergunakan dan kejelasan pikiran yang dikemukakan.

Berikut beberapa contoh tes kebahasaan yang bersifat pragmatik yakni:

a. Dikte

Dikte merupakan salah satu cara yang sering dilakukan untuk mengukur kemampuan berbahasa siswa. Jika urutan kata dan frase yang didiktekan berupa wacana (prosa, dialog, atau bentuk kegiatan berbahasa yang lain) kehidupan berbahasa yang wajar, dan jika penyajiannya dengan kecepatan yang wajar seperti halnya orang berkomunikasi sehingga menuntut siswa untuk mempergunakan kemampuan ingatannya. Dengan dikte, siswa dituntut untuk mampu memahami makna dari sesuatu yang didengar dan kemudian menuliskannya dengan sekaligus mengatasi kendala waktu.

Dikte tidak hanya menyangkut konteks linguistik saja, melainkan juga melibatkan konteks ekstralinguistik. Konteks linguistik adalah wujud bahasa sebagai suatu lambang verbal dengan segala aspek-aspeknya, sedang konteks ekstralinguistik adalah suatu "dunia", "sesuatu" yang berada di luar bahasa, "sesuatu" yang ingin disampaikan melalui alat bahasa.

Dikte menuntut kegiatan mental secara aktif dan kreatif. Oller dalam Nurgiyantoro (2001: 180) mengemukakan bahwa dikte sebagai tes kebahasaan sangat sesuai dengan kriteria validitas konstruk karena a) mencerminkan landasan teoritis tes kebahasaan, b) berkorelasi secara positif dengan tes kebahasaan lain yang sejenis, dan c) kesalahan-kesalahan dalam dikte berkaitan erat dengan kesalahan-kesalahan yang dibuat siswa dalam pemakaian bahasa secara nyata.

Prosedur dikte dapat dibuat secara bervariasi, dengan teknikteknik yang berupa dikte standar, dikte sebagian, dikte dengan gangguan suara, dikte-komposisi, dan produksi lisan imitasi (Oller dalam Nurgiyantoro, 2001: 180). Dalam dikte standar, siswa diminta menulis wacana yang dibacakan langsung atau melalui rekaman dengan kecepatan normal. Dikte yang dibacakan dengan lambat, pendek (misalnya satu kata atau suku kata tiap ucapan) tidak bersifat alami. Dalam dikte sebagian, dibacakan seperti dalam dikte standar, 
tetapi terdapat kata-kata tertentu yang dihilangkan. Tugas siswa adalah menulis kata-kata yang dihilangkan tersebut.

Dikte dengan gangguan suara adalah dikte yang disertai suara lain yang sengaja dimaksudkan untuk mengganggu suara yang didiktekan. Dikte komposisi (dictation-composition, disingkat: dictocomp), adalah dikte standar (prosa atau dialog) yang meminta siswa untuk mendengarkannya, dan setelah selesai, menuliskannya kembali dalam bentuk karangan. Prosedurer dalam produksi lisan imitasi (elicited imitation) pada hakikatnya tidak berbeda dengan diktekomposisi, hanya siswa diminta untuk menceritakan kembali secara lisan. Dalam dikte-komposisi dan produksi lisan, penilaian imitasi secara verbatim tidak tepat. Penilaian lebih tepat dilakukan seperti halnya dalam menilai kemampuan produkti, tertulis dan lisan.

b. Berbicara

Tes keterampilan berbicara seharusnya lebih mendapat perhatian karena paling mencerminkan kemampuan berbahasa seseorang (Oller dalam Nurgiyantoro, 2001: 181). Tes keterampilan berbicara (ekpresi lisan) yang bersifat pragmatic misalnya berupa interpretasi terhadap gambar susun (rangkaian gambar yang membentuk cerita) secara lisan, wawancara, baik secara terstruktur maupun tidak terstruktur.

c. Pemahaman Parafrase

Sebuah wacana singkat disajikan kepada siswa, lisan atau tertulis, kemudian siswa diminta untuk memilih salah satu dari beberapa paraphrase alternative yang disediakan yang maknanya paling sesuai dengan wacana. Contoh tes komprehensi mendengarkan atau menyimak dalam bahasa Indonesia adalah sebagai berikut:

Rangsang yang

diperdengarkan

Pram yang datang pukul 10.00 lebih dahulu daripada

Zan, tetapi terlambat satu jam daripada $\mathrm{Zul}$
Jawaban dalam lembar tugas

Pram datang paling dahulu

Zul datang sesudah Zan

*Zul datang sebelum Zan

Zan datang sebelum Pram 
d. Jawaban Pertanyaan

Tugas ini berupa tes komprehensi dengar (lisan). Sebuah pertanyaan yang diajukan melalui sarana pendengaran (rangsang yang diperdengarkan), dan diikuti beberapa alernatif jawaban secara tertulis yang terdapat dalam lembar tugas. Berikut contohnya:

Rangsang yang diperdengarkan Jawaban dalam lembar tugas

- Mahalkah buku pegangan - Bersama kawan-kawan yang diwajibkan itu?

- *Uangmu pasti mencukupi

- Beberapa jam yang lalu

- Tak seindah bentuknya

Pertanyaan yang diajukan dapat juga didasarkan pada wacana bentuk dialog yang diperdengarkan sebelumnya. Berikut contohnya:

Rangsang yang diperdengarkan

Suara pertama (laki-laki):

Halo, Tin, apa kabar?

Berapa lama kita rak berjumpa, ya?

Suara kedua (perempuan):

Baik! Sebenarnya aku masih senang

di rumah. Tetapi perkuliahan

hamper dimulai.

Suara ketiga (perempuan)

Kapankah kedua orang kawan itu

berjumpa.
Jawaban dalam lembar tugas

- Pada saat perkuliahan sudah berlangsung.

- Menjelang perkuliahan akan berlangsung.

- Menjelang perkuliahan sudah hampir selesai.

- Pada saat perkuliahan telah berakhir.

e. Teknik Cloze (Cloze Technique, Cloze Procedure, Cloze Test)

Istilah cloze berasal dari persepsi psikologi gestal yang merupakan proses "menutup" sesuatu yang belum lengkap. Dalam teknik cloze tempat kosong sengaja disediakan dalam suatu wacana dengan menghilangkan kata-kata tertentu yang kesekian (ke-n: ke-5, ke-6, atau ke-7). Tugas siswa dalam tes ini adalah mengisikan kembali kata-kata yang dihilangkan tersebut. Untuk mengisikan kembali katakata itu secara tepat, siswa dituntut menguasai sistem gramatikal bahasa dan harus dapat memahami wacana.

Untuk mengukur kemampuan berbahasa siswa, penyusunan teknik cloze harus dipilihkan wacana yang "memaksa" siswa untuk 
memahami wacana itu. Wacana yang sifat redundansinya (melimpah) tinggi sehingga mudah dikenal, tidak tepat dipilih karena wacana ini hanya menuntut kemampuan ingatan seperti halnya melengkapi pola visual di atas. Wacana teknis yang hanya dikenal oleh kelompok tertentu saja, sifat redudansinya tinggi, sehingga juga tidak baik dipergunakan.

Berikut contoh teknik cloze:

Dalam sebuah negeri ada seorang permaisuri tua, sedang raja negeri itu sudah lama mangkat. Permaisuri itu ........ (1) seorang putrid yang amat cantik......(2). Putri itu telah bertunangan dengan .......(3) anak raja yang jauh negerinya .........(4) sampai waktu akan kawin, putri...... (5) bersiaplah hendak berangkat ke negeri......(6).

Kata yang dihilangkan: (1) mempunyai, (2) parasnya, (3) seorang, (4) setelah, (5) itu, (6) tunangannya.

\section{Simpulan}

Penilaian hasil belajar psikomotor atau keterampilan harus mencakup persiapan, proses, dan produk. Penilaian dapat dilakukan pada saat proses berlangsung yaitu pada waktu peserta didik melakukan praktik, atau sesudah proses berlangsung dengan cara mengetes peserta didik. Penilaian ranah psikomotorik dalam pelajaran bahasa memerlukan teknik yang tepat. Ketepatan teknik penilaian yang dipilih akan menghasilkan informasi yang tepat terkait komptensi psikomotorik siswa. Tes pragmatik adalah tes untuk kompetensi psikomotorik yang ditawarkan dalam tulisan ini. Tes tersebut adalah dikte, berbicara, pemahaman paraphrase, jawaban pertanyaan dan teknik cloze. Pilihan ini sejalan dengan tujuan dari penilaian psikomotorik yaitu siswa mampu menggunakan alat dan sikap kerja, siswa mampu menganalisis suatu pekerjaan dan menyusun urut-urutan pengerjaan, siswa cepat mengerjakan tugas, siswa mampu membaca gambar dan atau simbol, dan siswa mampu mengserasikan bentuk dengan yang diharapkan dan atau ukuran yang telah ditentukan. 


\section{DAFTAR PUSTAKA}

Arifin, Zaenal. 1991. Evaluasi Instruksional, Prinsip, Teknik, Prosedur. Bandung: Remaja Rosdakarya.

Arikunto, Suharsimi. 2001. Dasar-dasar Evaluasi Pendidikan. Jakarta: Bumi Aksara.

Brown, Douglas. 2007. Prinsip Pembelajaran dan Pengajaran Bahasa. Jakarta: Kedutaan Besar Amerika Serikat.

Buttler, F. Coit. 1972. Instructional System Development for Vocational and Technical Training. Educational Technology Publication Inc. New Jersey: Englewood Cliffs

Domjan, Michael. 2005. The Essentials of Conditioning and Learning. Third Edition. Canada: Thomson Wadsworth.

Edwardes, HN. 1981. Bagaimana Membantu Orang Belajar Keterampilan. Padang: FPTK-IKIP Padang.

Goetz, P.W. 1981. The New Encyclopedi Britanica. Vol. 10, 15th. ed. Chicago: William Benton Publisher.

Hamalik, Oemar. 2008. Perencanaan Pengajaran Berdasarkan Pendekatan Sistem. Jakarta: PT. Bumi Aksara.

Hasan, Alwi, dkk. 2005. Kamus Besar Bahasa Indonesia. Jakarta: Departemen Pendidikan. Nasional Balai Pustaka.

Iskandarwassid dan Dadang Sunendar. 2008. Strategi Pembelajaran Bahasa. Bandung: UPI dan PT Remaja Rosdakarya.

Klein, Stephen B. 2002. Learning: Principles and Applications. Fourth Edition. New York: McGraw Hill.

Mardapi, Djemari. 2003. Penyusunan Tes Hasil Belajar. Yogyakarta: UNY.

Mills, H.R. 1977. Teaching and Training. London: The Macmillan Press, Ltd

Muijs, Daniel dan David Reynolds. 2008. Effective Teaching Evidence and Practice. Second Edition. London: Sage Publication.

Nurgiyantoro, Burhan. 2001. Penilaian dalam Pengajaran Bahasa dan Sastra. Yogyakarta: BPFE. 
Andi Nurwati

Peraturan Menteri Pendidikan Nasional Nomor 19 Tahun 2007 tentang Standar Pengelolaan. Jakarta: Direktorat Jenderal Manajemen Pendidikan Dasar dan Menengah.

Peraturan Menteri Pendidikan Nasional Nomor 20 Tahun 2007 tentang Standar Penilaian Pendidikan. Jakarta: Direktorat Jenderal Manajemen Pendidikan Dasar dan Menengah.

Peraturan Menteri Pendidikan Nasional Nomor 41 Tahun 2007 tentang Standar Proses. Jakarta: Direktorat Jenderal Manajemen Pendidikan Dasar dan Menengah.

Peraturan Pemerintah Nomor 19 Tahun 2005 tentang Standar Nasional Pendidikan. Jakarta: Direktorat Jenderal Manajemen Pendidikan Dasar dan Menengah.

Ryan, D.C. 1980. Characteristics of Teacher. a Research Study: Their Description, Comparation, and Appraisal. Washington, DC: American Council of Education.

Singer,R.N. 1972. The Psychomotor Domain: Movement Behavior. London: Henry Kimton Publisher.

Sudjana, Nana. 1991. Dasar-dasar Proses Belajar Mengajar. Bandung: Sinar Baru.

Walter. 2010. Pengaruh Terapi Kelompok Teraupetik terhadap Perkembangan Industri Anak Usia Sekolah di Panti Sosial Asuhan Anak Kota Bandung Tahun 2010. Tesis. Jakarta: Universitas Indonesia.

Winkel, WS. 2004. Psikologi Pengajaran. Yogyakarta: Media Abadi. 